\title{
Das teorias modernas de Estado à crítica da legitimação político-ideológica na organização social capitalista*
}

\author{
Gisele Masson ${ }^{l}$ \\ Universidade Estadual de Ponta Grossa
}

$\mathrm{O}$ presente artigo analisa as teorias do Estado moderno a partir da contribuição de autores clássicos da filosofia política como Hobbes, Locke, Rousseau, Kant, Hegel, Marx, Gramsci e outros. O objetivo desse estudo é apresentar um panorama das principais referências teóricas que deram sustentação à organização do Estado moderno bem como das discussões que foram empreendidas no sentido de desvelar a legitimação político-ideológica da organização capitalista presente em algumas teorizações.

Palavras-chave: Estado moderno Clássicos da filosofia política - Sociedade capitalista
This article analyzes the theories of the modern State from the contribution of classical authors of the political philosophy such as Hobbes, Locke, Rousseau, Kant, Hegel, Marx, Gramsci and others. The purpose of this article is to present an overview of the main theoretical references that have underpinned the organization of the modern State as well as the discussions that were carried out towards the unrevealing the political-ideological legitimation of the capitalist organization present in some theorizations.

Keywords: Modern state - Classics of the political philosophy - Capitalist society

$\mathrm{E}$ ste artigo focaliza o surgimento e desenvolvimento das teorizações sobre o Estado moderno a partir da seleção de autores clássicos da filosofia política moderna. Evidentemente, não será possível expor todas as teorias filosóficas sobre o Estado moderno, por isso, serão destacadas apenas as que tiveram uma influência proeminente no pensamento político.

Com base nos estudos de Gruppi (1986), o Estado moderno inicia na segunda metade do século XV, na França, na Inglaterra e na Espanha. Contudo, o primeiro a estabelecer uma reflexão sobre este Estado foi Maquiavel, na obra $O$ Príncipe. No início dessa obra, escrita em 1513, ele afirma: "Todos os Estados, todos os domínios que têm havido e que há sobre os homens, foram e são repúblicas ou principados" (MAQUIAVEL, 1999; p. 27).

\footnotetext{
*From modern theories of state to the critical of the political-ideological legitimation in the capitalist social organization

' Doutora em Educação e professora do Departamento de Educação da Universidade Estadual de Ponta Grossa (UEPG). Endereço para correspondências: Rua General Candido Rondon, 505, apt. 202, Nova Rússia, Ponta Grossa, PR, 88070-020 (gimasson@uol.com.br).
} 
Maquiavel contribuiu para o abandono, nos estudos políticos, dos fundamentos teológicos presentes na Idade Média.

A idéia de Estado está ligada à dominação sobre os homens, logo, a primeira característica do Estado moderno é a sua soberania, pois a sua autoridade não depende de nenhuma outra. A segunda característica se configura no século XVII, na Inglaterra, a partir da ascensão da burguesia e caracteriza-se pela distinção entre Estado e sociedade civil. A terceira característica que distingue o Estado moderno do Estado medieval é a de que ele deixa de ser patrimonial; o que ocorre é uma identificação do monarca com o Estado, representando o poder absoluto que ele detinha, emanado diretamente de Deus (GRUPPI, 1986).

A reflexão de Maquiavel não representa uma teoria do Estado moderno, mas sim uma teoria de como ele se forma, contribuindo para fundar a ciência política moderna. Sua obra foi considerada como uma espécie de manual do absolutismo.

As teorias que advogam a idéia de uma sociedade natural, ou seja, de que existe uma necessidade natural do homem de se associar com os outros são substituídas pelo advento da concepção contratualista que sustenta que a sociedade é o produto do acordo de vontades, de um contrato hipotético celebrado entre os homens. Apesar da substituição dos direitos divinos, a teoria clássica do Estado continua atribuindo a origem dos direitos a uma autoridade superior, pois advoga que a razão humana é concedida por Deus.

A formulação mais completa da teoria moderna do Estado, a partir dos pressupostos do contratualismo, foi dada pelo filósofo Thomas Hobbes na obra Leviat $\tilde{a}^{2}$, de 1651. Segundo ele, a natureza humana é causadora perene de desarmonia e de guerra; é o princípio do bellum omnium contra omnes, da guerra de todos contra todos, por isso, destaca que a primeira lei natural do homem é a da autopreservação. Ao explicar porque ocorre a guerra, desenvolve uma tese radicalmente antiaristotélica. Sua concepção de liberdade é negativa, pois é entendida como a ausência da restrição e da violência dos outros. Aristóteles parte da concepção de que o homem é um animal essencialmente político, tem liberdade positiva de participar do governo.

Entende que a vida em sociedade vai contra a essência de nossa natureza, assim, ao contrário da natureza sociável do homem "[...] os homens não tiram prazer algum da companhia dos outros - e, sim, até, um enorme desprazer -, quando não existe um poder capaz de manter a todos em respeito [...]" (HOBBES, 2002; p. 97). Desse modo, reafirma: "Torna-se manifesto que,

\footnotetext{
${ }^{2}$ Ribeiro (2006) destaca que "do Leviatã [...] se chegou a um razoável consenso: Hobbes escolheu o monstro citado no Livro de Jó porque ele reina sobre os filhos do orgulho e nós, humanos, somos antes de mais nada movidos por nossa vaidade, pela noção vã que temos de nosso valor: é esta, por sinal, a terceira causa da guerra generalizada entre os homens, da 'guerra de todos contra todos"' ( $p$. 32). Leviatã, na Bíblia, é um dragão, serpente ou crocodilo (Jó 3:8 e 40:20).
} 
durante o tempo em que os homens vivem sem um poder comum capaz de os manter a todos em respeito, eles se encontram naquela condição a que se chama guerra. Uma guerra que é de todos os homens contra todos os homens" (HOBBES, 2002; p. 98).

Assevera, portanto, a necessidade da constituição de um poder comum capaz de impedir essa condição natural do homem:

Todos devem submeter suas vontades à vontade do representante e suas decisões à sua decisão. Isso é mais do que consentimento ou concórdia, pois resume-se numa verdadeira unidade de todos eles, numa só e mesma pessoa, realizada por um pacto de cada homem com todos os homens, de modo que é como se cada homem dissesse a cada homem: "Cedo e transfiro meu direito de governar a mim mesmo a este homem, ou a esta assembléia de homens, com a condição de que transfiras a ele teu direito, autorizando de maneira semelhante todas as suas ações". Feito isso, à multidão assim unida numa só pessoa se chama Estado, em latim civitas. Esta é a geração daquele enorme Leviatã, ou antes - com toda reverência - daquele deus mortal, ao qual devemos, abaixo do Deus Imortal, nossa paz e defesa (HOBBES, 2002; pp. 130-31, grifo do autor).

Neste excerto, Hobbes declara ser partidário do absolutismo político, sem recorrer à noção de direito divino, pois o poder se explica não como dádiva divina, mas como construção para preservar a vida dos cidadãos. Assim,

Em vez do direito divino e da origem direta em Deus do poder estatal, Hobbes apela ao interesse em viver a salvo do medo da morte violenta, e à fundação do poder no contrato. Em vez de um condomínio entre a espada e o báculo, nosso autor subordina o clero ao soberano, que porta mais traços leigos do que religiosos: ele anexa a religião e o clero, mas sob a primazia de um Estado que se irá laicizando ao longo dos tempos (RIBEIRO, 2006; p. 27).

De acordo com Hobbes, o soberano só deve prestar contas a Deus, portanto, seu poder é absoluto, não tendo nenhuma obrigação em relação aos seus súditos, mas deve seguir somente as leis da natureza, ou seja, é obrigado a conservar a si mesmo, pois é o responsável pela garantia da proteção de todos. 
Além disso, o soberano deveria ter o poder de nomear seus sucessores, mas a burguesia inglesa jamais aceitou tal modelo de Estado por perpetuar o poder nas mãos de um único indivíduo ou grupo.

Sua filosofia a respeito da origem contratual do Estado exercerá enorme influência em outros pensadores e contribuiu para, no plano ideológico, fundamentar o desenvolvimento da Revolução Francesa. Hobbes é considerado o maior expoente do contratualismo.

Em Spinoza, a idéia de fundar a cidade apenas pelo uso da razão e do poder de uma única pessoa é uma falácia. Para ele, não existe razão sem paixão e não existe um que não seja múltiplo, por isso, o indivíduo e a massa não são opostos, contrariando o individualismo liberal. A política é apenas a continuação da guerra por outros meios e não a sua interrupção como acreditavam os contratualistas.

Em sua obra Tratado político ${ }^{3}$, escrita entre 1675-1677, afirma que o homem é sujeito às paixões. "Ora, estando os homens sujeitos, na maioria de seus atos, por sua natureza, às paixões, conclui-se, naturalmente, que os homens são inimigos" (SPINOZA, s.d:; p. 39). O estado de natureza é a guerra de todos contra todos, pois cada um procura a sua autoconservação, assim, o direito natural "não proíbe nada que eles não desejem ou não possam fazê-lo" (SPINOZA, s.d.; p. 38). Porém, sob a conduta da razão os homens procuram manter a paz e a liberdade e "tudo o que lhe é ordenado pela vontade geral é obrigado a obedecer [...]" (SPINOZA, s.d.; p. 40).

Destaca a importância da qualidade das instituições públicas para a garantia da paz, já que nem sempre é possível contar com as virtudes morais dos governantes. Para ele, a gênese da vida política não está na vontade de Deus, nem na razão ou virtude dos homéns, mas no próprio direito natural. A distinção de seu pensamento em relação à Hobbes reside na conservação do direito natural no direito civil, demonstrando que a vida política é uma outra dimensão da vida natural. "[...] o direito do Estado ou dos poderes soberanos outra coisa não é que o próprio direito natural, enquanto é determinado, não pelo poder de cada indivíduo, isoladamente, mas pelo da multidão, agindo como uma só alma" (SPINOZA, s.d.; p. 43).

Considera que não há obrigação pela conservação do contrato social, da mesma maneira que o homem no estado natural; quando o objetivo é a conservação comum os "contratos ou as leis pelas quais a multidão transfere o seu próprio direito às mãos de uma assembléia ou de um homem, sem dúvida que se deva violá-las, quando se trata da salvação comum" (SPINOZA, s.d.; p. 53).

\footnotetext{
${ }^{3}$ A obra Tratado político foi interrompida pela sua morte, portanto é uma obra póstuma e o capítulo que versa sobre a democracia está inconcluso.
} 
No Tratado político, o autor revela que o homem é a expressão da organização da sociedade, da sua ambiência social, pois "os homens não nascem próprios ou impróprios à condição social, senão que tais se tornam" (SPINOZA, s.d.; p. 55). Demonstra uma clara defesa à democracia, apesar de não ter desenvolvido completamente suas idéias. Nos capítulos que aborda sobre a monarquia e a aristocracia defende claramente as massas. Na forma monárquica, considera como necessidade de sua conservação a propriedade nacional do solo e dos produtos do comércio, propondo um plano coletivista ao afirmar "que os campos e todo o solo, e, se possível, as próprias casas, pertençam ao Estado, isto é, àquele que é depositário do direito do Estado, a fim de que as alugue, mediante um pagamento anual, aos habitantes das cidades e aos agricultores" (SPINOZA, s.d.; p. 62).

$\mathrm{Na}$ forma aristocrática, defende a proteção da propriedade privada dos bens, já que a sua manutenção é mais duradoura. "O governo confiado a uma assembléia suficientemente numerosa é um governo absoluto, ou ao menos naquele que o aproxima mais de um governo absoluto. Porque se há governo absoluto é aquele que reside nas mãos da multidão toda inteira" (SPINOZA, s.d.; p. 89).

A política, de acordo com ele, não elimina os conflitos e a paz nunca será definitiva, ela apenas possibilita operar com eles de um modo diferente do estado natural. Desse modo, os regimes políticos devem desenvolver a melhor forma de satisfazer os desejos dos homens. Protesta contra a paz da tirania ao afirmar que:

\begin{abstract}
Num Estado onde os súditos não se levantam em armas pelo só motivo de que os paralisa o temor, tudo o que se pode dizer, é que não há guerra, mas não se pode dizer que haja paz. Porque a paz não é a ausência da guerra. A paz é a virtude que nasce do vigor da alma, e a verdadeira obediência, é a vontade constante de executar tudo que deve ser feito segundo a lei comum do Estado. Assim, uma sociedade onde a paz não tenha outra base que a inércia dos cidadãos, os quais se deixam conduzir como rebanho e não se exercitam senão na escravidão, não é uma sociedade, é um ermo, uma solidão (SPINOZA, s.d.; p. 56).
\end{abstract}

Há, em sua obra, um avanço em relação à Hobbes no estabelecimento de um Estado democrático, algo que será gradativamente defendido pelos teóricos modernos. 
O inglês John Locke fundou o empirismo moderno, foi o primeiro teórico do liberalismo e é considerado como o verdadeiro filósofo da burguesia nascente. Inicialmente, era favorável ao absolutismo, tornando-se, mais tarde, num filósofo liberal, cujas teses fundamentaram as democracias liberais. Dois tratados sobre o governo civil foram publicados anonimamente, em 1689, embora a data (errônea) do editor seja de 1690 , mesmo ano de publicação de seu Ensaio sobre o entendimento humano (VÁRNAGY, 2006; p. 55). No Livro II deste ensaio, pergunta: "De onde apreende todos os materiais da razão e do conhecimento? A isso respondo, numa palavra, da experiência. Todo o nosso conhecimento está nela fundado, e dela deriva fundamentalmente o próprio conhecimento" (LOCKE, 1991; p. 28). Contrapôs-se, portanto, à doutrina das idéias inatas. "Uma vez estabelecida esta doutrina, isto é, que há princípios inatos, situou seus adeptos com a necessidade de receber certas doutrinas sem discussão, desviando-os do uso de suas próprias razões e julgamentos, e levando-os a acreditar nelas sem exame posterior" (LOCKE, 1991; p. 24). De acordo com Várnagy (2006):

As semelhanças entre os pensamentos de Hobbes e Locke podem ser sintetizadas nos seguintes pontos: a concepção individualista do homem, a lei natural como lei de autopreservação, a realização de um pacto ou contrato para sair do estado de natureza, e por último, a sociedade política como remédio contra os males e problemas do estado de natureza (p. 57).

A obra Segundo tratado sobre o governo inspirou as duas declarações dos direitos do homem, a dos Estados Unidos de 1787 e a da França de 1789, e será utilizada como principal referência, neste estudo, por explicitar suas principais idéias acerca do Estado moderno.

Locke não considera o Estado como uma criação de Deus, mas como um pacto consensual realizado entre homens livres, por isso, afirma: "[...] concordo que o governo civil seja o remédio correto para os inconvenientes do estado de natureza, que devem certamente ser grandes, se os homens têm de ser juízes em causa própria" (LOCKE, 2006; p. 28). Ao contrário de Hobbes, não considera que o pior seja a anarquia, mas sim o despotismo do soberano. "Opino que muito melhor será o estado de natureza, onde os homens não estão obrigados a submeter-se à vontade caprichosa de um rei [...]" (LOCKE, 2006; p. 28). Essa afirmação revela que o autor não considera o estado de natureza como um estado de guerra (posição assumida por Hobbes), mas alerta para a necessidade de não confundi-los: 
Quando os homens convivem segundo a razão, sem uma autoridade superior comum no mundo que possa julgar entre eles, verifica-se propriamente o estado de natureza. Todavia, o uso da força, ou sua intenção declarada, contra a pessoa de outrem, quando não existe qualquer instância superior comum sobre a Terra para quem apelar, configura o estado de guerra (LOCKE, 2006; p. 32).

Para Locke, somente quando certo número de indivíduos se reúne em sociedade para transferir para a comunidade o poder de executar a lei da natureza haverá sociedade civil ou política, assim, os homens saem do estado de natureza para entrarem no de comunidade. Considera a monarquia absoluta incompatível com a sociedade civil e propõe um poder legislativo que promulgará leis que mantenham a propriedade privada e a segurança dos indivíduos.

Supondo-se que o príncipe concentre em si todo poder, não só legislativo como executivo, não haverá juiz algum, e ninguém terá a possibilidade de apelar para alguém que julgue imparcialmente, com equilíbrio e autoridade e de cuja decisão se possa esperar reparação para qualquer dano ou transtorno causado pelo príncipe ou por sua ordem (LOCKE, 2006; p. 71).

Destaca a necessidade da conservação recíproca da vida, da liberdade e dos bens aos quais denomina de propriedade. Dessa maneira, afirma que "o maior e o principal objetivo, portanto, dos homens se reunirem em comunidades, aceitando um governo comum, é a preservação da propriedade. De fato, no estado de natureza faltam muitas condições para tanto" (LOCKE, 2006; p. 92). Entende que a propriedade privada já existia no estado de natureza e que "a extensão de terra que um homem lavra, planta, melhora, cultiva e de cujos produtos desfruta, constitui a sua propriedade. Pelo trabalho, digamos, destaca-a do que é comum" (LOCKE, 2006; p. 40). Pelo trabalho foi possível dar direito de propriedade sobre o que havia de comum na natureza e a limitação desse direito se dava pela capacidade de desfrutar dos bens, sem desperdício, sem deixar que os produtos perecessem. Entretanto, o uso do dinheiro promoveu a acumulação ilimitada da propriedade privada e a justificativa para as desigualdades entre os homens era dada pelo trabalho: 
[...] É evidente que os homens concordaram com a posse desigual e assimétrica da terra, tendo descoberto, pela aceitação tácita e espontânea, maneira de alguém possuir licitamente mais terra do que aquela cujo produto pode utilizar, recebendo em troca, pelo excesso de produto, ouro e prata que pode guardar sem causar dano aos outros, uma vez que estes metais não se deterioram nem se estragam (LOCKE, 2006; p. 50).

O contrato entre os homens origina tanto a sociedade quanto o Estado e o governo é o agente dessa sociedade. A sociedade civil é "um estado de paz entre seus membros [...]" (LOCKE, 2006; p. 145). Para Locke, é o povo que possui o poder soberano, enquanto que para Hobbes o monarca é soberano, embora ambos sejam contratualistas. Locke também apresenta uma distinção entre sociedade civil e sociedade política, entre público e privado.

A obra de Locke exibe um potencial revolucionário, pois ela dá legitimidade à rebelião do povo diante das injustiças perpetradas pelas autoridades. "Sempre que o legislativo tentar tomar ou destruir a propriedade do cidadão, ou subjugá-lo ao seu poder arbitrário, entra em estado de guerra com ele, isentando-o de ulterior obediência [...]" (LOCKE, 2006; pp.148-49). Porém, a dissolução do governo não representa a dissolução da sociedade (anarquia), como em Hobbes, mas é justificável para impedir o despotismo.

Apesar do aparente caráter democrático de sua obra, Locke justifica a desigualdade econômica pelos princípios da razão natural, assim, a participação na sociedade política é reservada aos proprietários e a cidadania é daqueles que possuem liberdade, a qual pressupõe ser proprietário. Para Várnagy (2006; p. 77), sua filosofia política ainda é considerada como central na fundamentação do Estado liberal democrático contemporâneo.

Dentre os contratualistas que merecem destaque no que diz respeito à teorização da constituição da ordem política é Rousseau. No Discurso sobre a origem $e$ os fundamentos da desigualdade entre os homens, publicado em 1755, demonstra uma posição contrária à de Hobbes ao defender a idéia de que o homem não é naturalmente mau, mas que o estado de natureza é "o mais próprio à paz e o mais conveniente ao gênero humano" (ROUSSEAU, 2006; p. 51). A condição natural do homem é de liberdade, de igualdade e de felicidade, a qual é destruída pela civilização. Para ele, não há liberdade sem a igualdade, mas refere-se à igualdade jurídica e reconhece que a desigualdade econômica gera uma série de problemas. Destaca que: 
O primeiro que tendo cercado um terreno se lembrou de dizer: Isto é meu, e encontrou pessoas bastante simples para o acreditar, foi o verdadeiro fundador da sociedade civil. Quantos crimes, guerras, assassínios, misérias e horrores não teria poupado ao gênero humano aquele que, arrancando as estacas ou tapando os buracos, tivesse gritado aos seus semelhantes: "Livrai-vos de escutar esse impostor; estareis perdidos se esquecerdes que os frutos são de todos, e a terra de ninguém!" (ROUSSEAU, 2006; p. 61).

O contexto no qual Rousseau concebeu essa obra foi o da entrada da França no desenvolvimento industrial capitalista. Preocupado em recuperar a essência do homem numa época em que a obtenção do lucro imperava sobre a vida das pessoas, julga que a propriedade fez desaparecer a igualdade, todavia, a sua concepção ignora que a origem da propriedade tenha surgido pelo desenvolvimento das forças produtivas. A dominação, a servidão, a violência ocasionaram uma desordem que impôs o "mais horrível estado de guerra". Dessa maneira, os homens perceberam a necessidade de "sacrificar uma parte de sua liberdade para a conservação da outra" (ROUSSEAU, 2006). Ao analisar essa questão, Rousseau se posiciona da seguinte maneira:

Tal foi ou deve ter sido a origem da sociedade e das leis, que deram novos entraves ao fraco e novas forças ao rico, destruíram sem remédio a liberdade natural, fixaram para sempre a lei da propriedade e da desigualdade, de uma astuta usurpação fizeram um direito irrevogável, e, para proveito de alguns ambiciosos, sujeitaram para o futuro todo o gênero humano ao trabalho, à servidão e à miséria (pp. 73-4)

No Discurso sobre a origem e os fundamentos da desigualdade entre os homens estabelece a diferença entre espaço público e privado, entre uma forma pré-social de relação entre os sujeitos, baseada nos afetos, na domesticidade, e a ordem social, baseada em convenções, em relações reguladas pelo direito e pela escolha racional.

A necessidade de um pacto social, de um contrato, constitui a sociedade. O estabelecimento da lei e do direito de propriedade fez surgir a desigualdade, pois do estado natural o homem foi conduzido ao estado civil. Afirma que: 
Tal é, com efeito, a verdadeira causa de todas essas diferenças: o selvagem vive em si mesmo; 0 homem sociável, sempre fora de si, não sabe viver senão na opinião dos outros, e é, por assim dizer, exclusivamente do seu julgamento que tira o sentimento de sua própria existência (ROUSSEAU, 2006; p. 87).

Considerava a propriedade como o direito mais sagrado do cidadão, mas o Estado deveria limitar os extremos de pobreza e riqueza a fim de propiciar certo grau de igualdade. Na obra Do contrato social, de 1762, demarca, com mais clareza, a diferença entre o espaço público e o privado: "[...] cada indivíduo pode ter como homem uma vontade particular, diversa ou dessemelhante da vontade geral que tem como cidadão [...]" (ROUSSEAU, 2007; p. 32). Entretanto, reforça a importância da obediência à vontade geral, caso contrário, o pacto social se torna um "vão formulário". O homem, com o contrato social, perde a sua liberdade natural e ganha a liberdade civil e o direito de propriedade. Por isso, enfatiza que
[...] Em lugar de destruir a igualdade natural, o pac- to fundamental substitui, ao contrário, por uma igualdade moral e legítima toda a desigualdade física, que entre os homens lançara a natureza, homens que podendo ser dessemelhantes na força, ou no engenho, tornam-se todos iguais por convenção e por direito (ROUSSEAU, 2007; p. 35).

O contrato é o principal emblema dos interesses burgueses e fundamenta o liberalismo. Rousseau (2007; p. 55, grifo do autor) deixa explícito esse posicionamento ao afirmar: "Se indagais em que consiste justamente o maior bem de todos, e qual deve ser o fim de todo sistema de legislação, achá-lo-eis resumido nestes dois objetos principais, a liberdade e a igualdade."

Rousseau sustenta que a soberania pertence ao povo, a qual é transferida ao governante. A vontade geral é, portanto, a verdadeira fonte do poder político, que pode estar.representada na figura do monarca, dos aristocratas dominantes ou de uma assembléia geral democrática. O poder político encontra sua justificação na vontade geral, e, ao fugir deste compromisso essencial, torna-se um poder degenerado. Suas idéias democráticas inspiraram os líderes da Revolução Francesa e contribuíram para a queda da monarquia absoluta, para a extinção dos privilégios da nobreza e do clero e para a tomada do poder pela burguesia. A defesa da liberdade individual foi imprescindível para reforçar o pressuposto de que o poder se origina nos indivíduos que instituem a sociedade e o Estado, e não possui origem divina como no Estado medieval. 
Hobbes defende o poder legislativo centralizado nas mãos de um só soberano, propõe, assim, um modelo absolutista. Locke e Rousseau destacam a necessidade da divisão de poderes a fim de se evitar o excesso de poder concentrado em um só corpo. Ambos afirmam a necessidade de uma assembléia para fazer as leis e outro poder para colocá-las em funcionamento.

Tanto para Hobbes quanto para Locke e Rousseau, o legislativo é o mais importante dos poderes e, ao destacarem a importância da troca da liberdade natural pela liberdade civil para a garantia da paz, desenvolveram uma abordagem teórica denominada de jusnaturalismo. A teoria contratualista se consolidou a partir dessa abordagem. Desse modo:

A tese central da teoria jusnaturalista é dada pela defesa da idéia de que os homens possuem direitos naturais, anteriores às normas fixadas pelo Estado. Embora se possa encontrar as origens da teoria do direito natural ou do jusnaturalismo na Antiguidade grega, é na sociedade moderna que suas idéias se transformam em instrumentos da luta política contra o poder do Estado medieval, por defenderem que os homens possuem direitos que encontram seu fundamento na natureza humana, os quais o Estado não pode violar (COSTA, 2006; pp. 25-6).

O filósofo alemão Emmanuel Kant é mais conhecido por suas obras Crítica da Razão Pura, Crítica da Razão Prática e Crítica do Juízo, entretanto, entre a primeira e a segunda crítica escreveu Fundamentação da Metafísica dos Costumes, publicada em 1785, estabelecendo as bases de uma Ética e abrindo caminho para os estudos de Direito e Moral. Em 1797, a primeira parte da Metafísica foi escrita com o título Doutrina do Direito. Desse modo, esse texto tem um significado histórico e político no debate sobre o Estado. É considerado como um dos maiores doutrinadores do modelo liberal de Estado. Nessa obra, enfatiza como princípio universal do Direito que toda ação é justa quando "não constitui um obstáculo à conformidade da liberdade do arbítrio de todos com a liberdade de cada um segundo leis universais" (KANT, 2005; p. 46).

Afirma que as leis jurídicas (leis do Direito) são leis morais, por isso, elas constituem uma subclasse das leis morais. O conceito moral do direito é uma autorização ou faculdade de fazer tudo o que é moralmente possível e de resistir pela força àquele que o impede de fazê-lo. "Uma lei (moralmente prática) é uma proposição que contém um imperativo categórico, uma ordem" (KANT, 2005; p. 42). 
O Direito, segundo ele, divide-se em natural, que se funda em princípios a priori, e em positivo, que tem por princípio a vontade do legislador, por isso, a passagem do estado de natureza ao estado social está fundada no dever. Somente no estado civil é possível determinar o que é de direito, pois no estado natural toda aquisição é provisória. Assim, a aquisição provisória é um princípio do direito privado, e os homens devem entrar no estado civil para garantir a propriedade peremptória. Para Kant,

O estado não-jurídico, isto é, aquele em que não há nenhuma justiça distributiva, é chamado de estado natural (status naturalis). A este estado se opõe não o estado social [...], que se poderia chamar de um estado artificial (status artificialis), mas sim o estado civil (status civilis), submetido à justiça distributiva; porque no próprio estado natural pode haver sociedades legítimas [...] (KANT, 2005; p. 144, grifo do autor).

Designa o primeiro e o segundo desses estados de direito privado e o terceiro de direito público. Na obra A paz perpétua, publicada pela primeira vez em 1795, afirma:

A paz entre os homens que vivem juntos não é um estado de natureza - status naturalis; - o estado de natureza é, antes, a guerra; quer dizer, um estado onde, embora as hostilidades não tenham sido quebradas, existe a constante ameaça de que isso aconteça. Portanto, a paz é algo que deve ser "instaurado", pois abster-se de romper as hostilidades não basta para assegurar a paz, e se os que vivem juntos não se deram mútuas seguranças - coisa que só no estado "civil" pode acontecer, - será cabível que cada um deles, tendo-as previamente requerido ao outro, o considere e trate, se se negar a dá-las, como a um inimigo (KANT, 1944; p. 33, grifo do autor).

O estado de natureza kantiano assimila-se ao estado de guerra hobbesiano. O argumento do autor é de que o estado de natureza é oposto ao estado civil, mas não o é em relação ao estado de sociabilidade. No estado de natureza só podem ser garantidas posições e posses de modo provisório, enquanto no estado civil essa garantia se torna perene através do direito público. Na obra Fundamentação da Metafísica dos Costumes, de 1785, Kant destaca a importância do imperativo categórico como lei prática que representa uma ação como 
objetivamente necessária, diferente de outros imperativos que são princípios da vontade, mas não leis. “[...] os imperativos não são mais do que fórmulas para exprimir a relação entre as leis objetivas do querer em geral e a imperfeição subjetiva da vontade desse ou daquele ser racional - da vontade humana, por exemplo" (KANT, 2006; p. 45).

A idéia de igualdade e homogeneidade é uma condição básica para a existência do contrato e da lógica do mercado. Há matizes liberais no seu pensamento ao destacar que "[...] é um princípio de política moral que um povo, ao se converter em Estado, deve fazê-lo segundo os conceitos jurídicos de liberdade e igualdade" (KANT, 1944; p. 98). Reconhece a diferença entre a igualdade formal e a igualdade real, pois a igualdade do súdito perante a lei convive com a desigualdade presente na sociedade civil. "Essa é a razão pela qual o pensamento de Kant captou melhor do que nenhum outro os interesses da burguesia, na medida em que permite dissociar o político como reino da igualdade formal do social como reino da desigualdade" (ROSSI, 2006; p. 191).

$O$ contrato representa a união das vontades particulares numa vontade geral, "[...] é necessário que todos juntos queiram esse estado, para que se institua uma unidade total da sociedade civil. Portanto, sobre as diferentes vontades particulares de todos é necessária ainda uma causa que as una para constituir a vontade geral [...]" (KANT, 1944; pp. 83-4). Afirma que:

É preciso sair do estado natural, no qual cada um
age em função de seus próprios caprichos, e con-
vencionar com todos os demais (cujo comércio é
inevitável) em submeter-se a uma limitação exterior,
publicamente acordada, e por conseguinte entrar num
estado em que tudo o que deve ser reconhecido
como o Seu de cada qual é determinado pela lei e
atribuído a cada um por um poder suficiente, que
não é o do indivíduo e sim um poder exterior. Em
outros termos, é preciso antes de tudo entrar num
estado civil (KANT, 2005; pp.150-51, grifo do autor).

É bastante conservador em relação ao poder do soberano por considerar que nenhum artigo da constituição pode dar direito de oposição ao soberano, caso este viole a constituição. "[...] o soberano da cidade tem em relação aos súditos somente direitos, não deveres [...]" (KANT, 2005; p. 160). Nenhuma revolução, portanto, é legítima contra o poder do soberano.

Em A paz perpétua, o referido autor defende o modelo republicano, destacando que a paz não é um estado natural e que o objetivo da política é estabelecer a paz entre as nações. "A constituição republicana, além da pureza de sua origem, que brota da clara fonte de direito, tem a vantagem de ser a mais propícia para chegar ao anelado fim: a paz perpétua" (KANT, 1944; p. 36). 
Todos os teóricos que defenderam teorias de conciliação entre os Estados fracassaram, mesmo uma das mais bem fundamentadas como a de Kant, por não questionarem "o princípio estruturador profundamente iníquo das próprias estruturas da reprodução material, que em última análise eram as responsáveis pelos antagonismos sempre reproduzidos" (MÉSZÁROS, 2002; p. 247).

Hegel foi o filósofo alemão do século XIX que contribuiu, no plano ideológico, para o desenvolvimento da revolução burguesa, embora empreenda severas críticas à concepção liberal, individualista. Para ele, o Estado liberal não é ético por se restringir à inviolabilidade da pessoa e da iniciativa privada, nos aspectos econômicos. Apesar da crítica ao Estado liberal, Hegel propõe uma solução bastante conservadora por atribuir ao monarca uma soberania estatal e ao considerar que o Estado político não deve ser determinado pela sociedade civil, mas que, ao contrário, ele a determine.

É importante destacar que o século XVIII foi marcado pela revolução industrial e o capital já produzira a separação do produtor dos seus meios de produção e as totalidades (a família patriarcal, o feudo, as corporações, a Igreja) foram substituídas pelo individualismo. O particular é cindido do universal e o problema filosófico que se impõe é impossibilitar que a anarquia se estabeleça, portanto, é um problema que diz respeito ao Estado.

As novas estruturas do mundo burguês já haviam se consolidado e a idéia kantiana da paz perpétua entre os Estados era claramente impossível. Dessa forma, Hegel definiu o Estado-Nação como "o poder absoluto na terra" e considerou o relacionamento entre os Estados como um estado de natureza. Segundo análise de Mészáros:

$\mathrm{Na}$ concepção idealista hegeliana, supunha-se que o Estado, como um "todo ético", teria de subordinar a si próprio (e assim superar) as contradições da sociedade civil, proporcionando-nos, objetivamente, "a verdadeira reconciliação que revela o estado como a imagem e a manifestação da razão" (MÉSZÁROS, 2002; pp. 448-49, grifo do autor).

Hegel estabelece uma crítica ao contratualismo e sua obra representa o rompimento com a concepção jusnaturalista. Para ele, "[...] a natureza do Estado não consiste em relações de contrato, quer de um contrato de todos com todos, quer de todos com o príncipe ou o governo. A inserção destas relações contratuais teve por resultado as mais graves confusões no direito público e na realidade" (HEGEL, 2005; p. 93). Em Hegel, a sociedade civil não era o estado de natureza organizado, mas aquilo que os naturalistas tinham designado como estado de natureza, um estado pré-político. 
De acordo com o autor, o império romano e a sociedade feudal correspondem ao Direito abstrato e formal, é o momento do universal abstrato. A modernidade corresponde à Moralidade, é o momento da particularização, é o desenvolvimento da moral particular do indivíduo, da moral kantiana criticada por ele. $\mathrm{O}$ terceiro momento corresponde à Eticidade, é o universal concreto em que o universal e o particular se superam e constituem o Estado. Desse modo, sua Filosofia do Direito representa a dialética entre:

a) O espírito moral objetivo ou natural: a família. Esta substancialidade se desvanece na perda da sua unidade, na divisão e no ponto de vista do relativo, tornando-se então:

b) Sociedade civil, associação de membros, que são indivíduos independentes, numa universalidade formal, mediante suas necessidades e a constituição jurídica como instrumento de segurança da pessoa e da propriedade e por meio de uma regulamentação exterior para satisfazer as exigências particulares e coletivas. Este estado exterior converge e reúne-se na

c) Constituição do Estado, que é o fim e a realidade em ato da substância universal e da vida pública nela consagrada (HEGEL, 2005; p. 155).

O indivíduo particular, considerado de forma independente de sua família, ou cidade é portador do direito de liberdade. Essa particularização demarca a diferença entre a antiguidade e a modernidade, refere-se à liberdade subjetiva que se inter-relaciona dialeticamente com a liberdade objetiva promovida pelo Estado.

Em sua obra Princípios da Filosofia do Direito, publicada em 1821, Hegel apresenta o Direito dividido em três esferas: Direito Abstrato, Moralidade Subjetiva e Moralidade Objetiva. No Direito Abstrato a vontade existe como pessoa, sendo livre enquanto detém direitos abstratos, cujo maior direito é a propriedade. Na Moralidade Subjetiva a vontade existe como sujeito e reivindica a sua subjetividade, o qual será livre quando atingir o Bem. Na Moralidade Objetiva a vontade corresponde ao cidadão livre na realização dos seus direitos particulares em conformidade com o Direito Universal.

As contradições serão resolvidas nas Instituições da Moralidade Objetiva: Família, Sociedade Civil e Estado, responsáveis pela mediação entre o particular e o universal. Somente no Estado é possível a conciliação entre interesses particulares e universais, responsável por promover a verdadeira liberdade da vontade. O Estado constitui, portanto, a síntese da Moralidade Subjetiva e da Eticidade ou Moralidade Objetiva, é o reino da liberdade realizada, é o espírito objetivo. O pressuposto é o da supremacia ontológica do Estado em relação à sociedade civil. Por isso, enfatiza que: 
O Estado é a realidade em ato da Idéia moral objetiva, o espírito como vontade substancial revelada, claro para si mesmo, que se conhece e se pen$\mathrm{sa}$, e realiza o que sabe e porque sabe. No costume tem o Estado a sua existência imediata; na consciência de si, no saber e na atividade do indivíduo, tem a sua existência mediata, enquanto o indivíduo obtém a sua liberdade substancial ligando-se ao Estado como à sua essência, como ao fim e ao produto da sua atividade (HEGEL, 2005; pp. 204-05).

A concepção de Estado ético hegeliano corresponde à idéia de que o particular (o mercado, a sociedade civil) se desenvolvem como momentos da realização de todos no universal concreto que é o Estado. Não é a subordinação do universal (Estado) ao particular (sociedade civil). Contrapondo-se à concepção liberal, Hegel sustenta a necessidade da intervenção do Estado: "Sempre é possível haver contradição entre os diversos interesses dos produtores e dos consumidores; e mesmo que, no conjunto, as corretas relaçôes por eles mesmos sejam estabelecidas, ainda assim poderá ser conveniente uma regulamentação intencional superior às duas partes" (HEGEL, 2005; p. 196). Sua concepção de Estado será alvo das críticas de Marx (2005):

Hegel qualifica o direito privado como o direito da personalidade abstrata ou como o direito abstrato. $\mathrm{E}$, na verdade, ele tem que ser desenvolvido como a abstração do direito e, com isso, como o direito ilusório da personalidade abstrata, assim como a moralidade desenvolvida por Hegel é a existência ilusória da subjetividade abstrata. Hegel desenvolve o direito privado e a moralidade como tais abstrações, contudo disso não se segue que o Estado, a eticidade, que os tem como pressupostos, não possa ser senão a sociedade (a vida social) dessas ilusões, mas é concluído, ao contrário, que elas são momentos subalternos dessa vida ética (p. 123, grifo do autor).

Marx (2005; p. 136, grifo do autor) critica Hegel por este se contentar com um Estado que possui uma existência autoconsciente do espírito ético o qual é determinante e "[...] não deixa que a sociedade se torne o determinante real, pois para isso é necessário um sujeito real e ele possui apenas um sujeito abstrato, uma imaginação". 
Hegel (2005; p. 268) afirma que "enquanto Estado, o povo é o Espírito em racionalidade substancial e em sua realidade imediata. É, portanto, o poder absoluto sobre a Terra. Com relação aos outros Estados, o Estado é, por conseguinte, soberanamente autônomo." Discordava de Kant quanto à possibilidade de uma paz perpétua entre os Estados, pois a soberania coloca uns perante os outros num estado de natureza, por isso, afirma que se as vontades particulares não obtêm um comum entendimento, os conflitos entre os Estados só podem ser resolvidos pela guerra.

Se para Hegel (2005; p. 242) a sociedade civil "é o campo de batalha dos interesses individuais de todos contra todos [...]", ele a define como bellum omnium contra omnes hobbesiano. Esse interesse particular deve, portanto, ser suplantado pelo universal, ou seja, pelo Estado, pois ele representa tal universalidade, o reino da eticidade. Há uma clara oposição entre sociedade civil e Estado.

Marx (2005; p. 68, grifo do autor) analisa a concepção de Estado de Hegel da seguinte maneira: "O Estado não reside na sociedade civil, mas fora dela; ele a toca apenas mediante seus 'delegados', a quem é confiado a 'gestão do estado' no interior dessas esferas. Por meio destes 'delegados' a oposição não é suprimida, mas transformada em oposição 'legal', 'fixa'." Há, pois, em Hegel um compromisso epistemológico enraizado no seio da sociedade burguesa.

Em Hegel a história mundial representa a manifestação do espírito, tem uma racionalidade, um fim último, que é a consciência e realização da liberdade. O Estado se torna o objeto da história do mundo ao conciliar a vontade universal e a vontade particular, realizando a liberdade que é objetivada por meio das leis. $O$ espírito do mundo hegeliano é o verdadeiro agente da história e os indivíduos são meros instrumentos subordinados à razão.

A visão individualista da natureza do conflito social foi uma premissa da filosofia de Kant e Hegel, ocasionando a não apreensão da realidade das estruturas materiais de dominação. "Assim, retratar o sujeito individual abstrato como criador e portador do conflito corresponde à necessidade - por mais inconsciente que seja - de idealizar o sistema prevalecente de intercâmbio socioeconômico e cancelar qualquer alternativa a ele" (MÉSZÁROS, 2002; p. 379 , grifo do autor).

Ao longo da modernidade ocorreram várias cisões: separação do homem dos seus instrumentos de trabalho, divisão social e técnica do trabalho, separação da sociedade civil e do Estado. A dominação e a exploração são empreendidas sob os princípios da igualdade e liberdade que se consolidam pela existência do Estado, assim, a legitimação autoperpetuante da política liberal foi desenvolvida no decorrer de todo o século XVIIII e XIX por diversos autores já analisados. A ruptura com a concepção liberal de Estado só ocorreu efetivamente com a contribuição dos estudos empreendidos a partir de Karl Marx. 
A Crítica da filosofia do direito de $\mathrm{Hegel}^{4}$, de 1843, caracteriza-se como uma minuciosa análise da obra hegeliana Princípios da Filosofia do Direito, realizada por Marx. Nesta obra, contrapõe-se à idéia de que o Estado é a base da sociedade civil, defendendo que a sociedade civil é a base do Estado. A ruptura com a concepção hegeliana do Estado é demonstrada pelo autor ao afirmar:

Nas minhas pesquisas cheguei à conclusão de que as relações jurídicas - assim como as formas de Estado - não podem ser compreendidas por si mesmas, nem pela dita evolução geral do espírito humano, inserindo-se pelo contrário nas condições materiais de exiștência de que Hegel, à semelhança dos ingleses e franceses do século XVIII, compreende o conjunto pela designação de "sociedade civil"; por seu lado, a anatomia da sociedade civil deve ser procurada na economia política (MARX, 2003; pp. 4-5, grifo do autor).

Assim, estabelece uma crítica à concepção de Estado de Hegel por considerar que ele inverte a relação determinante-determinado: "o produtor é posto como o produto de seu produto" (MARX, 2005; p. 31). Para Marx, a família e a sociedade civil são partes reais do Estado e se fazem a si mesmas, são a força motriz.

Segundo Hegel, ao contrário, elas são produzidas pela Idéia real. Não é seu próprio curso de vida que as une ao Estado, mas é o curso de vida da Idéia que as discerniu de si; e, com efeito, elas são a finitude dessa Idéia; elas devem a sua existência a um outro espírito que não é o delas próprio; elas são determinações postas de um terceiro, não autodeterminações [...] (MARX, 2005; p. 30 , grifo do autor).

Há, em Hegel, uma inversão do subjetivo no objetivo e do objetivo no subjetivo, já que ele parte do Estado e faz do homem o Estado subjetivado.

\footnotetext{
${ }^{4}$ Apesar de Marx ser bastante próximo do pensamento hegeliano ele se distancia gradativamente dessa concepção ao trabalhar como jornalista na Gazeta-Renana (jornal diário publicado em Colônia, de janeiro de 1842 a março de 1843) e pela preocupação com problemas que exigiam uma compreensão mais aprofundada das relações materiais existentes, especialmente ao se envolver na polêmica do roubo de madeira no vale do rio Reno. Nesse contexto, tem a oportunidade de questionar o modelo idealista hegeliano a partir da percepção dos problemas concretos da realidade na qual estava inserido.
} 
Ao contrário, "[...] não é a constituição que cria o povo, mas o povo a constituição" (MARX, 2005; p. 50).

Assim, o idealismo presente na concepção de Estado de Hegel é criticado da seguinte maneira:

Já esclarecemos que Hegel desenvolve apenas um formalismo de Estado. O verdadeiro princípio material é, para ele, a Idéia, a abstrata forma pensada do Estado como um Sujeito, a Idéia absoluta, que não guarda em si nenhum momento passivo, material. Diante da abstração dessa Idéia, aparecem como conteúdo as determinações do real formalismo empírico do Estado e, por isso, o conteúdo real aparece como matéria inorgânica, desprovida de forma (aqui: o homem real, a sociedade real etc.) (MARX, 2005; p. 130, grifo do autor).

Apesar de Marx ter questionado a teoria de Estado de Hegel, bem como a sociedade e o Estado burguês, seria equivocado deduzirmos que Hegel é o maior representante da teoria burguesa do Estado (BOBBIO, 1991; p. 21).

Marx foi o primeiro escritor político que une uma concepção realista do Estado a uma teoria revolucionária da sociedade, pois não possui uma concepção pessimista da natureza humana ou da história. (BOBBIO, 1991; pp. 2930). Apesar disso, Bobbio argumenta que não existe uma teoria política em Marx, posição enormemente rejeitada pelos expoentes do marxismo. Bobbio parte da idéia da:

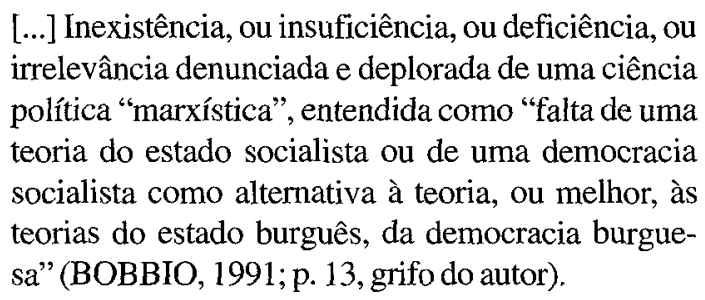

Na obra marxiana, há uma escassez de documentação sobre o Estado e não há uma teoria política, pois, segundo Boron (2006) a expressão teoria política marxista representaria a construção de uma teoria fragmentada tal como na ciência política conservadora, o que existe é:

\section{[...] Uma "teoria marxista" da política, que integra em seu seio uma diversidade de fatores explicati- vos que transcendem as fronteiras da política e que}


combinam uma ampla variedade de elementos procedentes de todas as esferas analiticamente distinguíveis da vida social (BORON, 2006; p. 31, grifo do autor).

Contudo, o tema do Estado, apesar de estar nos planos da obra $O$ Capital $^{5}$, não poderia ser desenvolvido por ele como uma nova teoria, já que defende a sua autossupressão gradativa. Ele jamais poderia fazer uma projeção de um Estado novo por defender a sua extinção, todavia há uma lacuna no pensamento marxiano como também marxista, de um modo geral, no que diz respeito à teoria do Estado de transição. Mészáros considera que

Não é, portanto, de modo nenhum surpreendente que Marx nunca tenha tido sucesso em sequer rascunhar os meros esboços de sua teoria de Estado, apesar de este receber um lugar muito preciso e importante no seu sistema projetado como um todo (MÉSZÁROS, 2002; p. 598).

Para Marx, a sociedade civil, ou seja, o conjunto das relações econômicas é que explica o surgimento do Estado. No prefácio da obra Contribuição à crítica da economia política, publicada em 1859, esclarece que:

O conjunto destas relações de produção constitui a estrutura econômica da sociedade, a base concreta sobre a qual se eleva uma superestrutura jurídica e política e à qual correspondem determinadas formas de consciência social. O modo de produção da vida material condiciona o desenvolvimento da vida social, política e intelectual em geral. Não é a consciência dos homens que determina o seu ser; é o ser social que, inversamente, determina a sua consciência (MARX, 2003; p. 5).

Nesse sentido, assevera que é a estrutura econômica que determina o Estado. Todavia, a concepção de que o Estado é uma superestrutura não pressupõe a idéia de que ele é menos importante, ou que é separado da sociedade civil, ao contrário, é parte integrante das relações de produção capitalistas por garantir sua reprodução. Marx entendia que o Estado não representa o bem comum, pois ele não está acima dos interesses particulares e das classes, mas é, sobretudo, a expressão política da dominação de uma classe sobre outra.

\footnotetext{
${ }^{5} \mathrm{O}$ estudo do Estado e da política estava presente no plano da obra $O$ Capital que foi interrompida pela sua morte. Ver sobre a estrutura da obra de Marx em Rosdolsky (2001).
} 


\section{Das teorias modernas de Estado à crítica da legitimação político-ideológica ...}

Marx rejeitou a eternização das relações históricas de produção, colocou em relevo o interesse ideológico da posição liberal e defendeu a abolição do Estado por meio de uma radical transformação da sociedade. Tal extinção não poderia acontecer por decreto, mas por uma série de medidas político-administrativas. Por isso, Mészáros afirma que

Nem o capital, nem o trabalho, nem sequer o Estado podem ser simplesmente abolidos, mesmo pela mais radical intervenção jurídica. Não é, portanto, de modo algum acidental que a experiência histórica tenha produzido abundantes exemplos de fortalecimento do Estado pós-revolucionário, sem dar sequer o menor passo na direção de seu "fenecimento" (MÉSZÁROS, 2002; p. 600, grifo do autor).

O fenecimento do Estado, imprescindível para a realização do socialismo, é inconcebível sem o fenecimento do capital, bem como da autotranscendência do trabalho da condição de subordinado do capital. "Nesse sentido, o afastamento estrutural objetivo das personificações do capital (em vez do políticojurídico insustentável por si mesmo) por meio de um sistema de auto-administração genuíno é a chave para a reconstrução bem-sucedida das estruturas herdadas" (MÉSZÁROS, 2002; p. 602, grifo do autor).

Marx considerava que o Estado representava a alienação dos indivíduos em relação ao poder de tomada de decisões, desse modo, defendia sua superação prática, não como mera abolição, mas como definhamento. Para ele, a emancipação humana radical só seria possível pela supressão da consciência social distorcida:

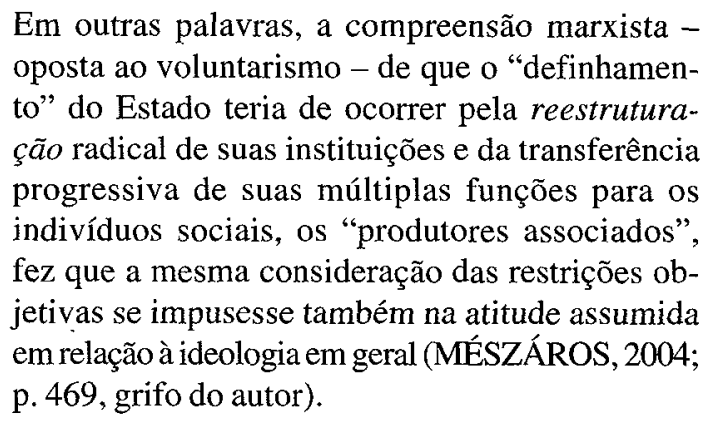

Assim, Marx apresenta uma concepção negativa da política o que não quer dizer uma anti-teoria ou uma não teoria. Boron (2006) esclarece a posição diferenciada do autor em relação aos principais filósofos políticos da modernidade: 
Marx percebeu a política e o Estado como instâncias supremas da alienação que preservavam a manutenção de uma sociedade baseada na exploração do homem pelo homem. É precisamente por isso que, onde Hobbes via um poder soberano pondo fim ao terror do homem sobre o homem e instaurando a paz despótica que permitia o desenvolvimento da sociedade de classe; e onde Locke percebia um "governo mínimo" que abria novos espaços para a acumulação de riquezas; ou onde Rousseau sonhava com a reconstrução de uma comuniđade democrática de homens sem desandar, não obstante, o caminho aberto por aquele enganador que fincara as estacas e dissera "esta terra é minha"; ou onde Hegel confiava no desdobramento da eticidade e do altruísmo universal, Marx encontrou um conjunto de práticas, instituições, crenças e processos mediante os quais a dominação de classe se coagulava, reproduzia e aprofundava (BORON, 2006; pp. 310-11, grifo do autor).

Marx questionou a igualdade jurídica postulada pela concepção burguesa, já que os direitos institucionalizados não possuem sustentabilidade real. A liberdade é uma quimera, pois o Estado liberal reforça uma pseudo-igualdade e não se responsabiliza pela desigualdade real. A existência do Estado sempre imporá a ditadura; somente a supressão do Estado permitirá o surgimento da verdadeira liberdade. A constituição política do Estado moderno é, para ele, a constituição da propriedade privada, logo, não haverá possibilidade do homem ser livre com o Estado. Enquanto garante, na aparência, a igualdade, em essência, o que existe é a desigualdade, pois a propriedade privada é reconhecida e legitimada pelo Estado.

O Estado socialista representaria a ditadura do proletariado em contraposição à ditadura da burguesia, porém seria apenas transitório a fim que o proletariado realizasse as tarefas que criariam as bases materiais para a consolidação do autogoverno dos produtores, do não-estado comunista.

No texto de Engels $A$ origem da família, da propriedade privada e do Estado, de 1884, há o argumento de que o surgimento do Estado ocorreu a partir de determinado grau de desenvolvimento, delimitando a posição dos homens nas relações de produção.

O Estado não é pois, de modo algum, um poder que se impôs à sociedade de fora para dentro; tampouco é "a realidade da idéia moral", nem "a imagem e a realidade da razão", como afirma Hegel. 


\begin{abstract}
É antes um produto da sociedade, quando esta chega a um determinado grau de desenvolvimento; é a confissão de que essa sociedade se enredou numa irremediável contradição com ela própria e está dividida por antagonismos irreconciliáveis que não consegue conjurar. Mas para que esses antagonismos, essas classes com interesses econômicos colidentes não se devorem e não consumam a sociedade numa luta estéril, faz-se necessário um poder colocado aparentemente por cima da sociedade, chamado a amortecer o choque e a mantê-lo dentro dos limites da "ordem". Este poder, nascido da sociedade, mas posto acima dela se distanciando cada vez mais, é o Estado (ENGELS, 1991; p. 19l, grifo do autor).
\end{abstract}

Para ele, é a formação das classes sociais e seus conflitos que fazem emergir o Estado como um controlador, demonstrando sua natureza de classe por atender os interesses daqueles que detém os meios de produção. Apesar de desvelar sua gênese, a qual a burguesia sempre tentou encobrir, Engels não desenvolveu uma análise mais aprofundada do Estado capitalista.

No século XX, Gramsci, na obra Maquiavel, a política e o Estado moderno, afirma que enquanto existir o Estado-classe, não pode existir sociedade regulada. A revolução que a burguesia promoveu na concepção do direito e na função do Estado "consiste na vontade de conformismo (logo, moralidade do direito e do Estado)" (GRAMSCI, 1989; p. 146). É necessário, segundo ele, entender o Estado além do aparelho governamental, mas também como aparelho privado de hegemonia ou sociedade civil. Assim, "[...] a direção do desenvolvimento histórico pertence às forças privadas, à sociedade civil, que é também 'Estado', aliás o próprio Estado" (GRAMSCI, 1989; p. 148, grifo do autor).

Gramsci desenvolve uma concepção ampliada de Estado ao enfatizar:

[...] A confusão entre sociedade civil e sociedade política, pois deve-se notar que na noção geral de Estado entram elementos que também são comuns à noção de sociedade civil (neste sentido, poderse-ia dizer que Estado $=$ sociedade política + socie dade civil, isto é, hegemonia revestida de coerção) (GRAMSCI, 1989; p. 149).

Fixa dois planos superestruturais: "o que pode ser chamado de 'sociedade civil' (isto é, o conjunto de organismos designados vulgarmente como 'privados') e o da 'sociedade política ou o Estado' [...]" (GRAMSCI, 2004; p. 20-1, grifo do autor). 
À sociedade civil corresponde a função de hegemonia exercida pelo grupo dominante e o domínio direto é exercido pelo Estado com o governo jurídico. Para Marx, a sociedade civil é estrutura e para Gramsci ela é superestrutura, por isso, o conceito de hegemonia é central nas análises deste último, pois só assim considerava possível explicar o consentimento das classes dominadas em relação ao modo de produção capitalista. O Estado moderno, em Gramsci, tem função coercitiva e hegemônica, sendo assim, destaca a importância das estratégias e das instituições que possibilitem a obtenção de consenso, dentre elas a escola e os tribunais.

[...] A escola como função educativa positiva e os tribunais como função educativa repressiva e negativa são as atividades mais importantes: mas, na realidade, no fim predominam uma multiplicidade de outras iniciativas e atividades chamadas privadas, que formam o aparelho da hegemonia política e cultural das classes dominantes (GRAMSCI, 1989; p. 145).

Ao contrário do príncipe de Maquiavel que representa o monarca, Gramsci utiliza o termo "moderno príncipe" com o significado de vontade coletiva, personificada no partido. "Este organismo já determinado pelo desenvolvimento histórico, é o partido político: a primeira célula na qual se aglomeram germes de vontade coletiva que tendem a se tornar universais e totais" (GRAMSCI, 1989; p. 6). Defendia a necessidade de o Partido Comunista desenvolver a educação das massas atrelada à ação política a fim de desenvolver uma contrahegemonia.

A análise do papel do Estado moderno é imprescindível para compreender como é possível a reprodução da organização social que engendrou o modo de produção capitalista. Entretanto, o Estado não se constitui como o alicerce fundamental do capital, mas sim o trabalho. A contradição entre capital, trabalho e Estado fundamenta o modo de produção capitalista.

Para Mészáros (2002), o sistema do capital é um sistema reprodutivo social antagonicamente estruturado porque apresenta defeitos estruturais de controle. A atual crise estrutural do capital afeta todas as instituições do Estado, o que ocasiona uma crise política em geral. Desse modo, o Estado moderno é uma estrutura corretiva adequada aos novos parâmetros estruturais do capital, por isso, sua função é retificar os problemas mais graves da crise, porém, sem superá-los definitivamente, pois isso demandaria a superação do próprio capital. Para esse autor,

Devido à inseparabilidade das três dimensões do sistema do capital plenamente articulado-capital, trabalho e Estado -, é inconcebível emancipar o trabalho sem simultaneamente superar o capital e o Estado. 
Pois, paradoxalmente, o pilar material fundamental de suporte do capital não é o Estado, mas o trabalho sem sua contínua dependência estrutural do capital (MÉSZÁROS, 2002; p. 600).

O antagonismo entre capital e trabalho está na base estrutural da sociedade capitalista e as constantes estratégias de reorganização para superação de crises não darão conta de rompê-lo, apenas minimizá-lo em alguns setores restritos.

\section{Considerações finais}

No presente artigo, procurei demonstrar a evolução das teorizações sobre o Estado moderno. Em Maquiavel tivemos o início da fundamentação da ciência política, por ser o primeiro a abordar a política de forma científica. Hobbes, teórico do absolutismo e partidário do regime monárquico, contribuiu para fundamentar a teoria moderna do Estado ao sistematizar o contratualismo. Spinoza deduz do estado naturalista o estado racional e considerava que a democracia é a forma mais natural de governo. Com Locke, o contratualismo foi desenvolvido em bases liberais, opondo-se ao absolutismo de Hobbes. Rousseau, embora pertencesse à corrente contratualista, se opôs à Hobbes e Spinoza, pois não considerava que o estado natural era de guerra mútua. Para ele, no estado de natureza os homens são livres e iguais.

Kant buscou fundamentar um sistema capaz de encerrar o estado de guerra permanente no qual se encontravam os Estados. Considerava que a transição do estado de natureza para o estado civil é uma forma de possibilitar o exercício dos direitos naturais através do domínio estatal. No contratualismo kantiano, a liberdade do estado de natureza deve ser deixada em favor da aquisição da liberdade com autonomia para criar as leis para si próprio. Os autores contratualistas divergem sobre a condição humana no estado de natureza, mas concordam que este deve ser superado através da união dos indivíduos por meio do estabelecimento de um contrato.

Hegel criticou o contratualismo por considerar que não há pacto entre indivíduo e Estado. Segundo ele, é o Estado que funda a sociedade, pois é no Estado que se torna possível a conciliação entre interesses particulares e universais e a promoção da verdadeira liberdade da vontade.

Marx, Engels e Gramsci estabeleceram uma crítica ao Estado moderno capitalista ao destacarem que a contradição entre as classes fundamentais (proletários e capitalistas) é reproduzida no interior do Estado, demonstrando que a classe econômica dominante é a classe política dominante. 
Apesar de algumas diferenças no pensamento desses três autores, eles enfatizaram a natureza de classe do Estado e sua função coercitiva. Assim, a análise das mudanças no papel do Estado moderno, ao longo da história é relevante, mas deve acontecer a partir do desvelamento do processo de produção do capital pela exploração do trabalho. Toda teoria de Estado, ao ser analisada, requer a articulação dialética com os fundamentos que possibilitam a produção e reprodução do capital.

\section{Referências bibliográficas}

BOBBIO, N. Existe uma doutrina marxista do Estado? In: $O$ marxismo e o Estado. $3^{\text {a }}$ Edição. Rio de Janeiro: Graal, 1991.

BORON, A. Filosofia política e crítica da sociedade burguesa: o legado teórico de Karl Marx. In: BORON, A. (Org.). Filosofia política moderna: De Hobbes a Marx. Pp. 287-328. São Paulo: CLACSO, DCP-FFLCH, USP, 2006.

COSTA, L. C. da. Os impasses do Estado capitalista: uma análise sobre a reforma do Estado no Brasil. São Paulo: Cortez, 2006.

ENGELS, F. A origem da família, da propriedade privada e do Estado. Rio de Janeiro: Bertrand Brasil, 1991.

GRAMSCI, A. Maquiavel, a política e o Estado moderno. $7^{\text {a }}$ Edição. Rio de Janeiro: Civilização Brasileira, 1989.

GRAMSCI, A. Cadernos do Cárcere. $3^{\text {a }}$ Edição, volume 2. Rio de Janeiro: Civilização Brasileira, 2004.

GRUPPI, L. Tudo começou com Maquiavel: as concepções de Estado em

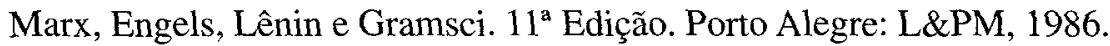

HEGEL, G. W. F. Princípios da filosofia do direito. $2^{\text {a }}$ Edição. São Paulo: Ícone, 2005.

HOBBES, T. Leviatã ou matéria, forma e poder de um Estado eclesiástico e civil. São Paulo: Martin Claret, 2002.

KANT, I. A paz perpétua. Rio de Janeiro: Vecchi, 1944.

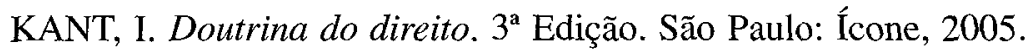

KANT, I. Fundamentação da metafísica dos costumes e outros escritos. São Paulo: Martin Claret, 2006. 


\section{Das teorias modernas de Estado à crítica da legitimação político-ideológica ...}

LOCKE, J. Ensaio acerca do entendimento humano. $5^{\text {a }}$ Edição. São Paulo: Nova Cultural, 1991.

LOCKE, J. Segundo tratado sobre o governo. São Paulo: Martin Claret, 2006.

MAQUIAVEL, N. O príncipe. 31 a Edição. Rio de Janeiro: Ediouro, 1999.

MARX, K. Contribuição à crítica da economia política. $3^{a}$ Edição. São Paulo: Martins Fontes, 2003.

MARX, K. Crítica da filosofia do direito de Hegel. São Paulo: Boitempo, 2005.

MÉSZÁROS, I. Para além do capital: rumo a uma teoria da transição. São Paulo: Boitempo, 2002.

MÉSZÁROS, I. O poder da ideologia. São Paulo: Boitempo, 2004.

RIBEIRO, R. J. Thomas Hobbes, ou: a paz contra o clero. In: BORON, A. (Org.). Filosofia política moderna: De Hobbes a Marx. Pp. 19-44. São Paulo: CLACSO, DCP-FFLCH, USP, 2006.

ROSDOLSKY, R. Gênese e estrutura de O Capital de Karl Marx. Rio de Janeiro: EDUERJ; Contraponto, 2001.

ROSSI, M. Aproximações ao pensamento político de Immanuel Kant. In: BORON, A. (Org.). Filosofia politica moderna: De Hobbes a Marx. Pp. 189212. São Paulo: CLACSO, DCP-FFLCH, USP, 2006.

ROUSSEAU, J. J. Discurso sobre a origem e os fundamentos da desigualdade entre os homens. São Paulo: Martin Claret, 2006.

ROUSSEAU, J. J. Do contrato social. São Paulo: Martin Claret, 2007.

SPINOZA, B. Tratado político. Rio de Janeiro: Ediouro, sem data.

VÁRNAGY, T. O pensamento político de John Locke e o surgimento do liberalismo. In: BORON, A. (Org.). Filosofia política moderna: De Hobbes a Marx. Pp. 45-80. São Paulo: CLACSO, DCP-FFLCH, USP, 2006. 